\title{
PENERAPAN PERANCANGAN PADA PENATAAN RUANG PAMER KERAJINAN KERAMIK DI KELURAHAN DINOYO KECAMATAN LOWOKWARU KOTA MALANG
}

\author{
Didiek Soeharjanto \\ Dosen Prodi Arsitektur, Fak. Teknik Sipil dan Perencanaan, ITN Malang \\ e-mail: suharjantodidiek@gmail.com \\ Adhi Widyarthara \\ Dosen Prodi Arsitektur, Fak. Teknik Sipil dan Perencanaan, ITN Malang \\ e-mail: adtha5@yahoo.com \\ Hamka \\ Dosen Prodi Arsitektur, Fak. Teknik Sipil dan Perencanaan, ITN Malang \\ e-mail: hamka07@lecturer.itn.ac.id
}

\begin{abstract}
ABSTRAK
Ruang pamer pada kawasan pengrajin keramik Dinoyo yang memiliki fungsi memberikan informasi tentang produk terkini maupun produk yang banyak digemari oleh masyarakat memberikan fasilitas yang terbatas pada pengunjung karena ruang yang ada dioptimalkan untuk penyimpanan produk keramik sehingga kurang memperhatikan sirkulasi untuk manusia dan barang pada tatanan ruangnya. Kenyamanan pelayanan pada pengunjung menuntut perlunya menciptakan suasana ruang dengan tema sesuai potensi bangunan, merencanakan sirkulasi manusia dan barang dengan membatasi jenis barang maupun jumlah perabot; memperhatikan letak pintu, jendela agar pencahayaan maupun penghawaan sesuai dengan kebutuhan; serta menyesuaikan ketinggian plafon agar pengunjung tidak merasa tertekan secara psikologis apabila memasukinya. Perlu melakukan penataan jenis komoditi sesuai dengan kelompok berdasarkan sifat kegunaannya, penampilan bentuknya serta mutu barang untuk memudahkan pengunjung melakukan pemilihan, maupun pengamatan terhadap barang yang dikehendakinya.
\end{abstract}

\section{Kata kunci : fungsi, perancangan ruang, penataan komoditi}

\begin{abstract}
The exhibition room at Dinoyo ceramic artisan area which has the function of providing information about the latest products and products that are much favored by the community provide limited facilities to the visitors because the existing space is optimized for storage of ceramic products so that less attention to the circulation for humans and goods on the spatial order. The convenience of service to the visitor demands the need to create an atmosphere of space with theme according to the potential of the building, planning
\end{abstract}


the circulation of people and goods by limiting the type of goods and the amount of furniture; pay attention to the location of doors, windows for lighting and penghawaan as needed; and adjust the ceiling height so that visitors do not feel depressed psychologically when entering it. Need to make the arrangement of commodity types according to the group based on the nature of its use, the appearance of the shape and the quality of goods to facilitate the visitors make the selection, as well as observation of the goods wanted.

\section{Keywords : function, space design, commodity arrangement}

\section{PENDAHULUAN}

Keberadaan ruang pamer pada kawasan pengrajin keramik Dinoyo, selain sebagai etalase produk kerajinan juga sebagai tempat penyimpanan dari hasil proses kerajinan keramik. Selama ini ruang yang difungsikan sebagai ruang pamer, pada awalnya merupakan bagian dari ruangan pada suatu rumah tinggal. Banyaknya permintaan akan produk keramik, menjadi pemicu untuk melakukan alih fungsi dari ruang tersebut; berkaitan dengan prinsip ekonomis, maka ruang tersebut difungsikan secara optimal untuk menampung produk keramik. Sesuai kondisi yang ada, menunjukkan suasana ruang pamer tersebut terkesan sesak karena banyaknya barang dagangan, kemudian juga terjadi tumpang tindih fungsi ruang pamer dengan ruang kerja serta tempat penyimpanan barang, sehingga pada akhirnya menjadi kurang menarik untuk dikunjungi bagi mereka yang ingin membeli barang produk kerajinan keramik.

Tidak adanya tatanan ruang yang berupa pendaerahan, menjadikan sulitnya mencari dan mendapatkan barang yang menjadi kebutuhan para pengunjung. Sesuai potensi yang ada, kawasan ini merupakan produsen keramik yang berupa vas bunga, guci maupun souvenir; produk yang paling diminati oleh pengunjung pada dekade terakhir adalah souvenir. Secara umum, perletakan produk oleh pemilik ruang pamer dibedakan menjadi beberapa area yang menuntut aktivitas yang spesifik. Area bagian depan difungsikan untuk meletakkan barang-barang produk baru atau sering dipesan oleh pengunjung, hal tersebut sering dijumpai dari aktivitas para pengunjung yang sedang mengamati untuk kemudian memilih berbagai jenis barang kerajinan keramik yang menarik bagi mereka. Sedangkan area belakang difungsikan untuk meletakkan barang-barang stok lama maupun koleksi, juga kemasan kardus-kardus pesanan yang siap diambil maupun tempat bekerja melakukan pengepakan benda keramik serta untuk melakukan transaksi maupun pembayaran antara pengunjung dan pengelola. Kedua area tersebut tidak terpisah secara permanen karena 
hanya dibatasi oleh elemen-elemen ruang yang bersifat semi-fixed yang berupa perabot seperti rak atau almari dan juga meja. Suasana seperti ini sangat mengganggu proses pemilihan produk karena keberadaan kardus berada pada fasilitas untuk sirkulasi pengunjung serta barang yang diperdagangkan. Selama ini, jenis komoditi yang merupakan produk kerajinan pada ruang pamer diletakkan dalam rak terbuka dan lemari kaca, adapun jenis produknya dikategorikan menjadi 3; kategori pertama adalah barang produk terbaru maupun yang banyak diminati oleh pengunjung, kategori kedua adalah barang yang sudah diproduksi cukup lama namun masih diminati oleh kolektor, sedang kategori ketiga adalah barang pelengkap yang berfungsi untuk melengkapi komoditi dagangan dan biasanya bukan produk pengrajin setempat misalnya guci maupun produk gerabah.

Penataan fisik ruang yang dibatasi oleh dinding, lantai dan plafon, oleh sebagian besar pemilik ruang pamer keberadaan dinding bagian depan dijadikan sebagai pembatas ruang yang transparan, baik berupa jendela maupun pintu yang menggunakan material kaca sehingga berfungsi memasukkan cahaya alami sebagai sumber pencahayaan maupun mengkomunikasikan kepada pengguna jalan tentang jenis barang yang dipamerkan atau dijual. Potensi elemen pembatas tersebut, ternyata tidak diikuti dengan pola tatanan perabot rak sebagai tempat komoditi yang memanfaatkan sumber pencahayaan. Lantai yang ada masih menggunakan material lama pada saat ruang tersebut merupakan bagian dari rumah tinggal, sehingga belum berfungsi sebagai pengarah sirkulasi bagi pengunjung serta belum ada kejelasan untuk perletakan rak komoditi. Plafon yang ada, juga masih belum memiliki desain khusus untuk perletakan titik lampu sebagai sumber pencahayaan buatan guna kenyamanan pengunjung untuk memilih benda komoditi. Terbatasnya luasan dan keinginan mengoptimalkan fungsi ruang, menyebabkan penataan ruang kurang memenuhi prinsip kenyamanan untuk pengunjung maupun pengelola dalam menjalankan aktivitas.

Ruang pamer kerajinan keramik, merupakan unsur penting untuk memberikan informasi tentang produk kerajinan terbaru sebagai objek pamer utama, produk kerajinan yang banyak diminati oleh pengunjung sebagai objek pamer penunjang serta produk kerajinan yang berupa barang kolektor sebagai objek pelengkap. Oleh karenanya, penataan ruang perlu ditata agar menarik pengunjung untuk menggali pengetahuan dan menyajikan informasi serta mengaktifkan respon pengunjung terhadap objek pamer dan memberikan kesan kepada pengunjung. Hindari penataan objek pamer yang monoton (De Chiara, 1980), juga diperlukan fleksibilitas pada penataannya sehingga mudah untuk dipindahkan maupun dimodifikasi agar dapat memberikan kesan suasana baru bagi pengunjung, serta tatanan objek komoditi pada rak agar mudah dijangkau oleh pengunjung. 
Persyaratan yang perlu diperhatikan dalam perencanaan ruang pamer, menurut Lawson (1981) adalah; penghawaan, penghawaan alami dapat menerapkan sistem ventilasi silang yang ada pada dua sisi ruang agar penghawaan dapat mengalir dengan lancar, sedangkan penghawaan buatan dapat menggunakan air conditioner; pencahayaan, disarankan pada ruang pamer memanfaatkan pencahayaan alami karena menghemat biaya operasional.

Tujuan penerapan perancangan pada penataan ruang pamer kerajinan keramik di Kelurahan Dinoyo Kecamatan Lowokwaru Kota Malang adalah untuk mendapatkan suasana ruang dengan tatanan objek pamer yang unik dan menarik, sehingga sesuatu yang sifatnya spesifik akan menjadi karakter sekaligus daya tarik ruang pamer kerajinan keramik Dinoyo guna mengkatkan animo masyarakat untuk mengunjungi kampung wisata keramik sekaligus dapat meningkatkan pendapatan masyarakat di kawasan kerajinan keramik ini.

\section{TINJAUAN PUSTAKA}

Ruang, menurut (Haryadi, 2010) adalah sistem lingkungan binaan terkecil yang sangat penting, terutama karena sebagian besar waktu manusia modern saat ini banyak dihabiskan di dalamnya. Dalam kajian arsitektur lingkungan perilaku, ruang diartikan sebagai suatu petak yang dibatasi oleh dinding dan atap baik oleh unsur yang permanen maupun tidak permanen. Ada dua macam ruang yang dapat mempengaruhi perilaku, pertama adalah ruang yang dirancang untuk memenuhi suatu fungsi dan tujuan tertentu; kedua, ruang yang dirancang untuk memenuhi fungsi yang lebih fleksibel. Masing-masing perancangan fisik ruang tersebut memiliki variabel independen yang berpengaruh terhadap perilaku pemakainya, hal tersenbut adalah ukuran dan bentuk, perabot dan penataannya, warna serta unsur lingkungan ruang (suara, temperatur dan pencahayaan).

Menurut Gerard J Tellis (1995), display interior adalah penyusunan barang dan banyaknya ragam barang yang terdiri dari berbagai jenis dan merk yang disusun secara cermat agar memberikan daya tarik dari dalam toko, adapun elemen yang penting dari display interior adalah : 1. Product supplying (pengadaan barang), yang perlu diperhatikan disini adalah pengadaan dan kemudahan memperoleh barang, oleh karena itu dibutuhkan petunjuk-petunjuk yang dapat memberitahukan dimana letak barang yang diinginkan konsumen; 2. Product grouping (pengelompokan barang), diperlukan untuk mengklasifikasi semua jenis barang yang ditawarkan sesuai dengan bentuk, ukuran dan merek barang dagangan yang sejenis; 3 . Product arranging (penyusunan barang), diperlukan untuk menampilkan barang dan yang perlu diperhatikan dalam penyusunan barang ini adalah tentang kebersihan, kerapihan, pencahayaan. 
Penyelesaian permasalahan penataan pada ruang pamer, menurut (Ching, 2007; De Chiara, 1980; Neufert, 2012) adalah :

- Fleksibilitas penggunaan ruan untuk bermacam-macamg, adalah suatu sifat kemungkinan dapat digunakannya sebuah ruang untuk bermacammacam sifat dan kegiatan serta dapat dilakukannya pengubahan susunan ruang sesuai dengan kebutuhan tanpa mengubah tatanan bangunan.

- Sirkulasi, merupakan aspek terpenting dalam perancangan ruang pamer karena terkait dengan kenyamanan pengunjung. Alur sirkulasi dapat dibayangkan sebagai benang yang menghubungkan ruang-ruang sehingga saling berhubungan (Ching,2007). Pengarahan sirkulasi dilakukan agar kegiatan pameran dapat berjalan lebih menarik.

- Penghawaan, perlu adanya ventilasi udara yang cukup untuk ruangan yang tidak menggunakan penghawaan buatan. Penggunaan ventilasi silang sangat penting agar sirkulasi udara dapat mengalir dengan baik. Ketentuan dalam penerapan ventilasi silang, yaitu lubang penghawaan minimal 5 persen dari luas lantai dan udara yang mengalir masuk samadengan dengan volume udara yang mengalir keluar ruangan.

- Pencahayaan, merupakan salah satu faktor penting dalam keberhasilan tata display objek pamer. Pencahayaan diatur agar tidak mengganggu koleksi maupun menyilaukan pengunjung. Penggunaan cahaya buatan dapat lebih memberikan efek yang lebih bagus jika dibandingkan dengan pencahayaan alami, namun efek pencahayaan alami dapat memberi kesan lebih hidup.

- Penataan objek pamer dan penyajian dalam ruang, terkait dengan penataan objek pamer ada 3 jenis penataan objek, yaitu : 1 . Ion showcase, benda yang dipamerkan termasuk kecil karenanya dibutuhkan wadah atau kotak tembus pandang yang kadang juga memperkuat kesan dari benda yang dipamerkan. 2. Free standing on the floor, on plinth or support, benda yang dipamerkan dimensi yang cukup besar sehingga memerlukan panggung/ketinggian tertentu sebagai batas objek pamer tersebut. 3. On walls or panel, benda yang dipamerkan di dinding ruang atau partisi pembatas ruangan..

\section{METODE PENELITIAN}

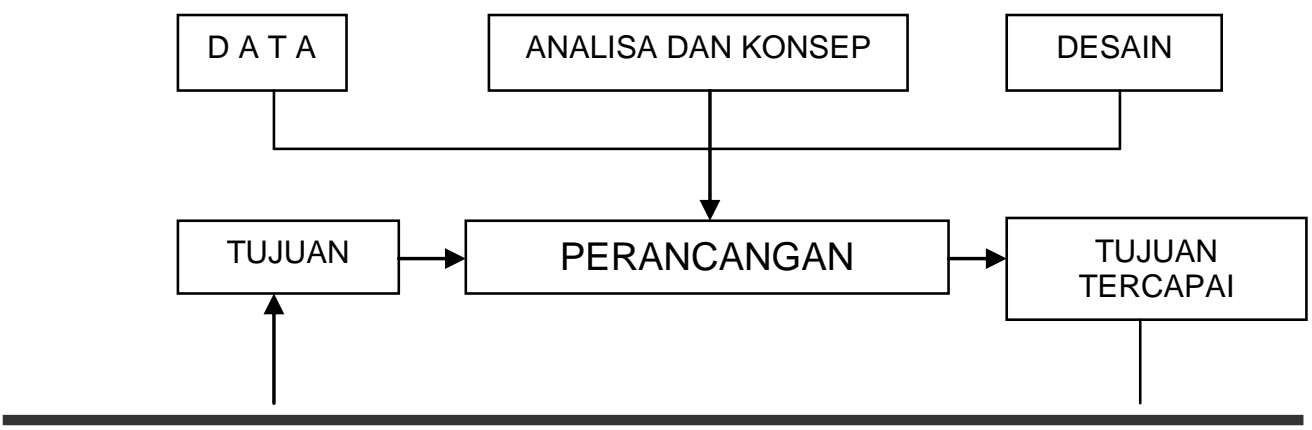

Jurnal PAWON, Volume II Nomor 02, Juli-Desember 2018, ISSN 2597-7636 


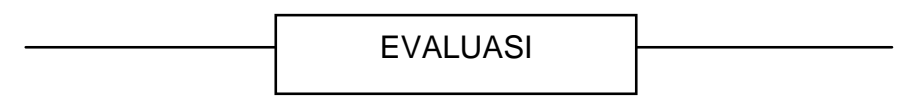

\section{Gambar 1}

Diagram Penerapan Perancangan pada Penataan Ruang Pamer

Pengumpulan data lapangan, dılakukan dengan mendapatkan informasi tentang ruang pamer yang diinginkan untuk penataan melalui pertemuan dengan para pemilik; pengumpulan informasi tentang potensi penjualan komoditi dari yang paling laku dijual, rutin laku dijual serta yang paling tidak laku dijual; melakukan pendataan ukuran serta tatanan komoditi pada ruang pamer; mengetahui fungsi ruang, sirkulasi dan pembagian ruangnya, serta mendokumentasikan suasana ruang pamer.

Melakukan analisa tentang perencanaan kegiatan yang berorientasi pada pemenuhan kebutuhan akan prasarana ruang pamer yakni meja dan kursi untuk pemilik maupun pembeli dalam bertransaksi tentang objek yang diminati, locker untuk tempat tas maupun rak untuk tempat objek komoditi yang memenuhi kenyamanan jangkauan maupun saat melakukan pengamatan serta pemilihan komoditi yakni unsur perletakan tertinggi maupun perletakan paling rendah. Sedangkan analisa perancangan tata letak meliputi kegiatan pengelompokan komoditi; kenyamanan sirkulasi pemilik, pekerja maupun pengunjung; keberadaan penghawaan maupun pencahayaan.

Menetapkan konsep rancangan guna pendayagunaan keberadaan ruang; terwujudnya tatanan ruang yang menunjang perwujudan citra visual produk keramik yang nyaman dan unik; optimalisasi fungsi ruang dengan memberikan ruang pandang yang menarik serta kenyamanan saat mengamati maupun memilih objek komoditi yang diminati; perlunya sirkulasi maupun pencapaian yang disesuaikan dengan potensi dan permasalahan ruang; penentuan zonasi objek komoditi.

\section{HASIL DAN PEMBAHASAN}

Berdasarkan tuntutan kebutuhan akan fasilitas ruang pamer yang nyaman dan unik, diperlukan :

1. Data Ruang Pamer, meliputi :

a. Optimalisasi fungsi ruang, sesuai tuntutan perilaku pemilik, pekerja dan pengunjung yang ada, meliputi kebutuhan ruang untuk memamerkan berbagai produk keramik antara lain souvenir, vas bunga, guci, lampu set serta produk yang mengikuti mode yang sedang berlangsung; ruang kerja untuk melakukan sortir maupun pengepakan serta kebutuhan penunjang kegiatan yang berupa gudang, ruang transisi serta kamar kecil. 
b. Penataan objek pamer atau komoditi, dengan pengelompokan tiga bagian objek yakni objek utama, objek penunjang serta objek pelengkap. Objek utama terdiri dari berbagai produk souvenir terbaru, produk souvenir yang banyak peminatnya, serta produk keramik untuk konsumsi kolektor. Objek penunjang merupakan produk alternative yang terbuat dari material gips serta objek pelengkap yang pada umumnya memiliki karakter berbeda dari objek utama maupun penunjang dari sisi ukuran serta motif dekorasinya.

c. Sirkulasi pengunjung dan pengelola, memerlukan karakteristik terkait dengan perilaku pengunjung dalam pemilihan produk keramik serta ruang interaksi antara pemilik dan pengunjung pada ruang penerima; sedangkan pengelola membutuhkan ruang sosial antara pemilik dan pekerja agar konsentrasi maupun efektivitasnya dalam bekerja dapat tercapai.

d. Suasana ruang yang menyebabkan kenyamanan dalam berinteraksi antara pemilik maupun dengan sesama pengunjung; serta dengan benda yang menjadi objek yang dipamerkan sehingga kesan kepadatan tidak terjadi.

2. Analisa Kegiatan, meliputi :

a. Fungsi ruang, merupakan wadah kegiatan interaksi antara produk kerajinan, pengelola maupun pengunjung, ruang pamer produk kerajinan yang terdiri dari produk terbaru, produk koleksi serta produk pelengkap, ruang informasi produk.

b. Bentuk dan dimensi ruang, bentuk bangunan yang beragam karena merupakan bagian dari rumah tinggal yang memiliki dimensi ruang dengan lebar 3 meter hingga 8,1 meter dan panjang mulai 1,5 meter hingga 8 meter.

c. Pengelompokan objek komoditi, beberapa objek diantaranya adalah produk terbaru, produk yang digemari pengunjung atau konsumen serta produk yang digemari kolektor.

d. Organisasi ruang, mengingat fungsi tunggal, maka hanya perletakan fungsi ruang pamer didekatkan dengan tempat kerja demikian juga fungsi tambahan yakni kamar kecil diletakkan dekat dengan ruang pamer.

e. Karakteristik ruang, masih terjadi tumpang tindih antara ruang pamer dengan ruang kerja serta tidak semua ruang pamer memiliki fasilitas penunjang yakni kamar kecil bagi pengunjung.

3. Konsep Perancangan, meliputi :

a. Penerangan, ruang pamer perlu memperhatikan keberadaan potensi penerangan alami ataupun buatan, sehingga ruang pamer menjadi lebih menarik dan menjadikan omset penjualan meningkat. 
b. Penghawaan, perlu direncanakan dengan penghawaan alami sebaik mungkin dan apabila tidak memungkinkan perlu dipikirkan penghawaan buatan agar pertukaran udara dapat tercapai dengan optimal agar kenyamanan termal terpenuhi.

c. Efektivitas dan efisiensi ruang, diperlukan tatanan objek pamer dengan ruang interaksi yang memudahkan pengunjung untuk memilih, mendapatkan informasi tentang benda yang diminatinya serta proses pembayaran yang mudah sehingga dapat memnuhi kebutuhannya secara cepat. Proses yang cepat tersebut, mungkin perlu ditunjang oleh keberadaan fasilitas katalog dari benda koleksi beserta harganya, dengan aktivitas yang mudah dan cepat dalam pemenuhan kebutuhan benda keramik tersebut diharapkan efesiensi ruang dapat tercapai.

d. Material, perlu digunakan material dinding yang memiliki permukaan licin sehingga mudah untuk dibersihkan apabila terdapat debu diruangan, akan lebih baik apabila menggunakan produk lokal untuk mempromosikan keunggulannya sehingga masyarakat semakin mudah untuk mengenali dan membelinya. Hal yang sama juga berlaku untuk lantai, namun dengan tekstur yang kasar agar para pengelola dan pengunjung dapat dengan aman dan nyaman dalam beraktifitas maupun berinteraksi, sedangkan untuk plafond menggunakan material yang murah dan mudah diganti karena suasana ruang dapat disesuaikan dengan tatanan benda yang menjadi objek pamer.

e. Warna, menggunakan jenis warna yang memiliki gelombang yang panjang, sehingga memancarkan bias warna yang kuat dan digolongkan sebagai warna hangat. Adapun jneis warna tersebut adalah warna merah hingga warna kuning hijau.

4. Produk Desain, meliputi :

a. Kenyamanan ruang, perlunya penataan rak untuk objek komoditi pada susunan yang memudahkan sirkulasi bagi pengunjung untuk mengamati dan memilih benda yang diinginkan; demikian juga bagi pengelola untuk membantu pemenuhan kebutuhan dari pengunjung.

b. Mengusahakan prinsip sirkulasi kegiatan yang linier untuk meminimalkan terjadinya persimpangan antar manusia dan barang, memperhatikan antropometri manusia sebagai pelaku aktivitas, melakukan penataan barang komoditi berdasarkan yang paling laku hingga yang kurang laku dengan proses penataan dengan irama serta memberikan pembatas ruang yang memantulkan warna terang sehingga akan memudahkan pengunjung dalam pemilihan benda komoditi. 
Tabel 1.

Usulan Penerapan penataan Ruang Pamer Kerajinan Keramik Dinoyo

\begin{tabular}{lll}
\hline Sungsu Jaya \\
$\begin{array}{l}\text { Souvenir } \\
(3,6 \times 6,3)\end{array}$
\end{tabular}




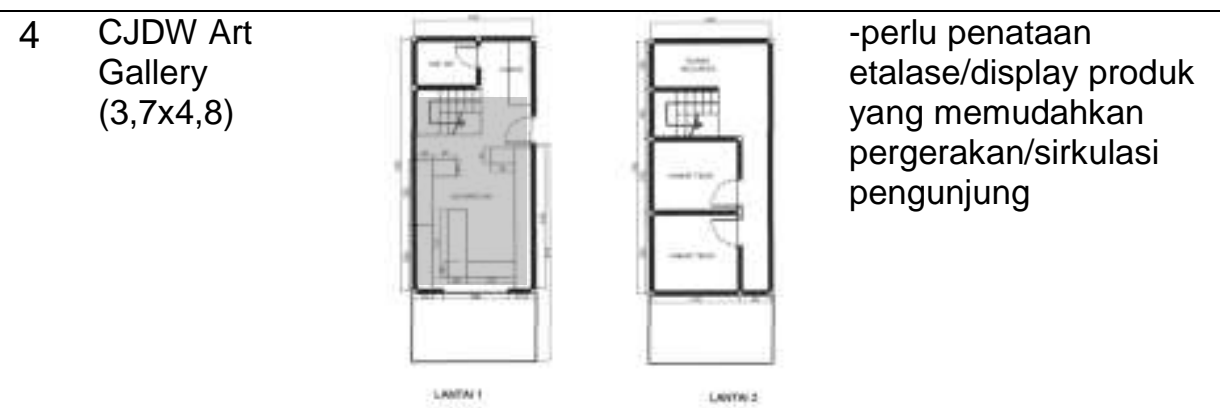

\begin{tabular}{llll}
\hline No $\begin{array}{l}\text { Showroom } \\
(8,1 \times 7,0)\end{array}$ & $\begin{array}{l}\text { Usulan Penerapan } \\
\text {-perlu penataan } \\
\text { etalase/display produk } \\
\text { pada bagian tengah } \\
\text { showroom yang } \\
\text { memudahkan } \\
\text { pergerakan/sirkulasi } \\
\text { pengunjung }\end{array}$ \\
\hline $\begin{array}{l}\text { Keramik Firman } \\
(4,5 \times 6,6)\end{array}$ & $\begin{array}{l}\text {-perlu penataan } \\
\text { etalase/display produk } \\
\text { pada bagian tengah } \\
\text { showroom yang } \\
\text { memudahkan } \\
\text { pergerakan/sirkulasi } \\
\text { pengunjung }\end{array}$ \\
\hline 7 & $\begin{array}{l}\text { Gito Gips \& } \\
\text { Souvenir }\end{array}$ &
\end{tabular}




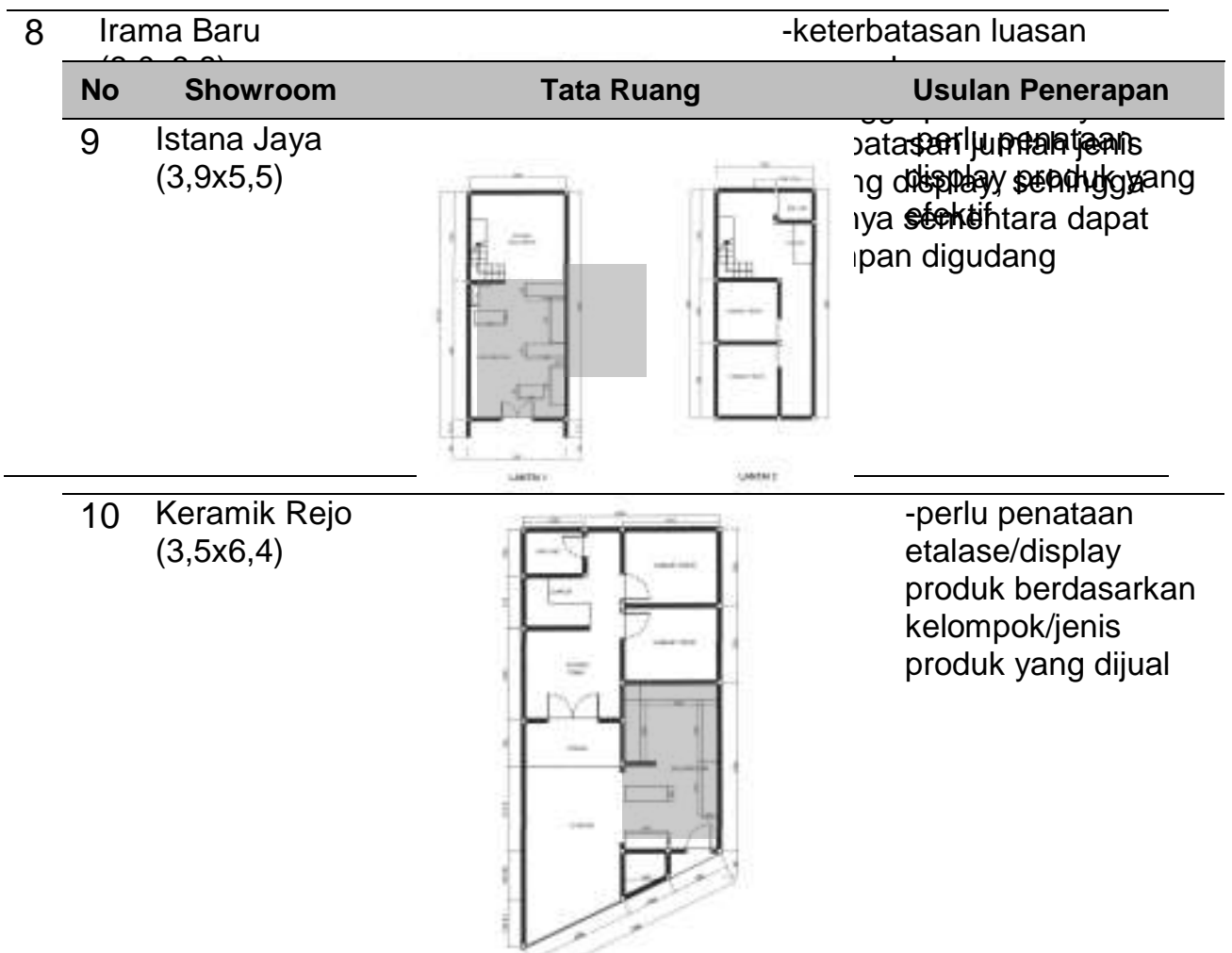

11 Kita Gips \& Souvenir $(4,3 \times 1,5)$

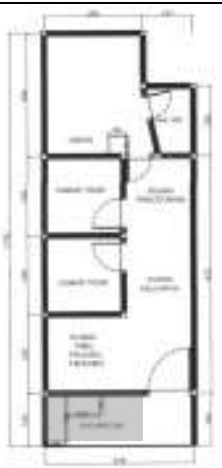

-keterbatasan

luasan ruang

showroom, sehingga perlu adanya pembatasan jumlah jenis barang display, sehingga stoknya sementara dapat disimpan digudang
12 Langgeng

Keramik $(3,0 \times 2,8)$
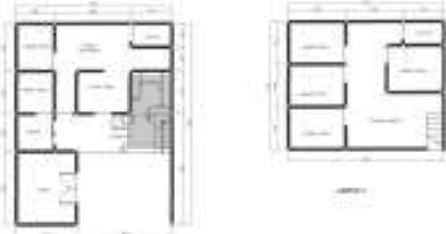

$-$ -keterbatasan

luasan ruang showroom, sehingga perlu adanya pembatasan jumlah jenis barang display, , sehingga stoknya sementara dapat disimpan digudang. 


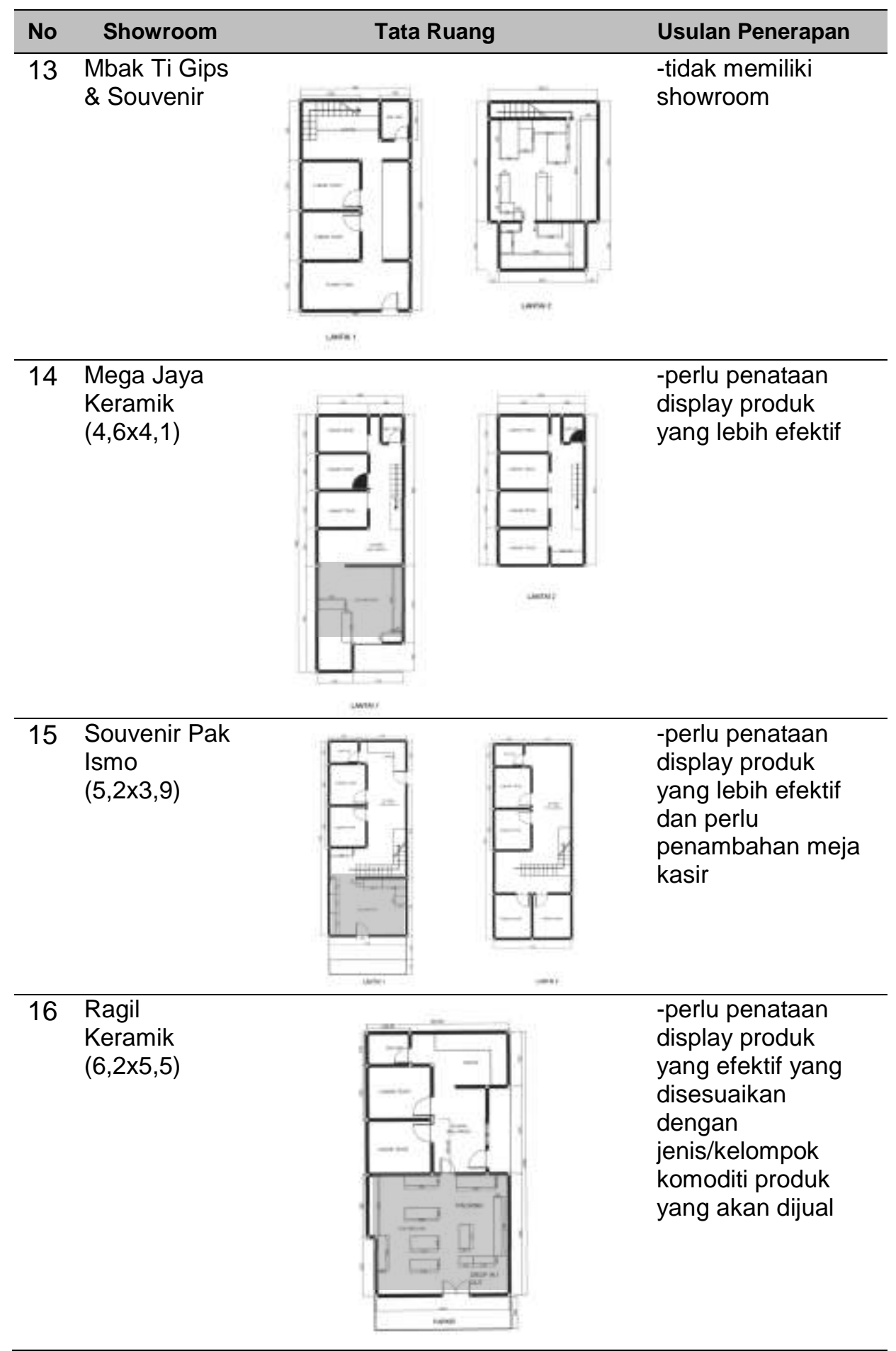




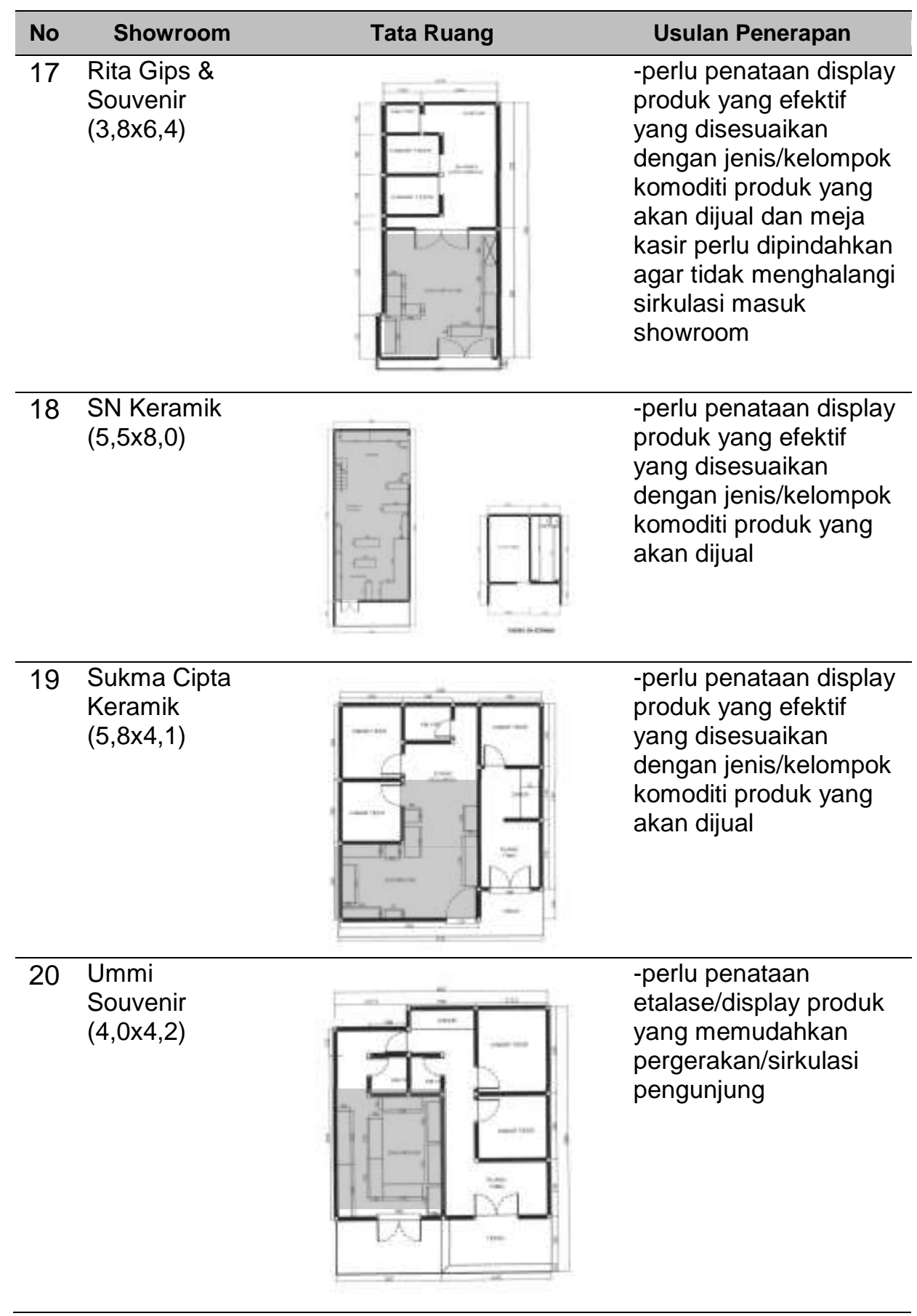




\begin{tabular}{llll}
\hline No & Showroom & Tata Ruang & Usulan Penerapan \\
\hline 21 & $\begin{array}{l}\text { La Rich } \\
\text { Souvenir } \\
(5,7 \times 5,6)\end{array}$
\end{tabular}

22 Yans Keramik $(6,4 \times 6,0)$

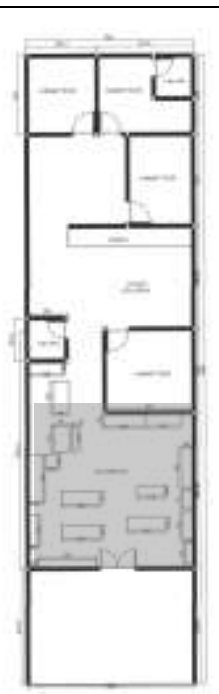

-Area showroom yang cuku luas masih dimungkinkan untuk penambahan display produk dan display perlu ditata lagi untuk mempermudah pengunjung mencari produk yang diinginkan, posisi meja kasir perlu dipindah kearea yang lebih cepat dijangkau

\section{KESIMPULAN}

Berdasarkan pada objek-objek showroom yang dikaji hasilnya ditemukan bahwa permasalahan utama yang terdapat pada sebagian besar ruang pamer keramik di Dinoyo adalah keterbatasan luasan ruang pamer yang dimiliki oleh para penjual atau pengrajin keramik, sehingga untuk mendapatkan kualitas ruang pamer yang nyaman dan sesuai dengan 
standar minimal akan sulit didapatkan, untuk itu perlu penyelesaian dari segi manajemen penataan jenis dan jumlah produk yang akan didisplay.

Beberapa showroom hanya perlu penataan ulang agar pola pergerakan pengunjung terhadap ruang gerak dan sirkulasi dapat lebih efektif, serta perlu pengelompokkan area display yang berdasarkan jenis/kelompok komoditi keramik yang akan dijual. Dari semua objek showroom yang dikaji hanya terdapat beberapa showroom yang memiliki luasan ruang yang cukup seperti milik Yans Keramik, SN Keramik, Ragil Keramik, Istana Jaya, CJDW, dan Bungsu Jaya.

Perlunya menciptakan ruang transisi untuk pengunjung yang akan masuk pada ruang pamer serta ruang interaksi di dalam ruang, agar pengunjung dapat berinteraksi dengan ruang pamer maupun suasana ruang untuk memudahkan aktivitas dalam mengamati maupun memilih komoditi yang diminati.

\section{DAFTAR PUSTAKA}

De Chiara, Joseph \& Callender John. 1980. Time Saver Standards for Building Types. USA: Mc Graw-Hill Inc.

Ching, FDK. 2007. Form, Space \& Order. Jakarta : Penerbit Erlangga.

Stallabrass, Julian. 2004. Contemporary art Introduction. New York: Oxford University Press Inc.

Tellis, Gerard J and Doyle L. Weiss. 1995. Does TV Advertising Realy Affect Sales ? The Role of Measures, Models and Aggregation, Journal of Advertising, Fall, Volume XXIV, Number 3.

Lawson, Fred. 1981. Conference, Convention and Exhibition Facilities. London: The Architectural Press. 
